\title{
WEEKLY NEWSPAPER "NASHE SLOVO" (WARSAW) IN THE CONTEXT OF THE FORMATION OF UKRAINIAN STATEHOOD
}

\author{
Taras Balda?
}

\begin{abstract}
This article analyses creation and development of weekly newspaper "Nashe Slovo" (Our Word) and its role in the protection of Ukrainian identity. Also the author analyzes the role of newspaper in strengthening of Ukraine-Polish relations and the maintenance of Ukrainian national identity in Poland.
\end{abstract}

Keywords: Ukraine, newspaper, identity, journalism.

Periodicals are one of the main sources of information about the political, economic and cultural life of any national minority in any country. Ukrainian press, that was published beyond country borders during period of statelessness reflects and unites all the waves of Ukrainian emigration for over 50 years. It was reflecting the period of Ukrainians' resettlement from their ethnic lands to the foreign countries and life of those Ukrainian communities, which were a minority among the population of other countries.

In general, Ukrainian communities published over 600 periodicals in different countries and almost on every continent of the world. Ukrainian press abroad wasn't persecuted and controlled by Soviet Union censorship as it was with the periodicals that were published in Ukraine, which looked like Ukrainian only according to the language and style, but didn't represent actually Ukrainian standpoint. It is an enormous loss for modern scholars, who studied the development of Ukrainian press abroad, that very few copies of those newspapers remained tour days. Z. Sokolyuk mentioned reasonably: "Ukrainian émigré periodicals are not completely preserved in one concrete place and this, in terms of its cultural and political development, is a great loss" [Sokolyuk, 1965, p. 24].

It's hard to express the overall scale of such a loss, because of the fact that the Ukrainian newspapers have been published not only in Europe and North America (USA and Canada) but also in South America, Australia, Asia and even in North Africa. Some of them did not exist for a long period of time, but still they had a huge influence on the 
life of Ukrainian community abroad. "The history of Ukrainian press is the history of Ukrainian people" [Kedryn, 1986, p. 264]. With its help scholars can fill the gaps in the history.

According to the different statistics, nowadays there are between 13 and 15 million Ukrainians and their descendants outside of Ukraine (not including the current Ukrainian guest workers) who were scattered throughout the continents. In particular, Poland became home for about 400 thousand of our compatriots who constitute one of the largest national minorities in the country. For centuries many Ukrainians live in the historic areas of Bojkowszczyzna, Lemkovshchyna, Podlasie, Chełm and Nadsanie. To meet Ukrainian needs there are a lot of Ukrainian public organizations. There is also Ukrainian-language newspaper "Nashe Slovo", which is analyzed in this article.

Ukrainian press in Poland, as well as periodicals published in other countries, where Ukrainians lived, played an important role in preserving national identity of Ukrainian emigrants. Scholars who study the Ukrainian periodicals in Poland had fewer problems with access to primary sources of weekly newspaper "Nashe Slovo", since it was the oldest periodical newspaper in Poland and for a long time it was the main printed organ of Ukrainian Social and Cultural Society in Poland. Nowadays it is Ukrainian-Polish weekly newspaper, which is available in libraries and on the Internet.

For 60 years of its existence weekly newspaper "Nashe Slovo" has made a great contribution to the preservation of Ukrainian national identity. That is why it is important to analyze it thoroughly.

"Nashe Slovo" appeared in Poland in the wake of a so-called political thaw in 1950s. The first issue of the newspaper came out of print in June 15, 1956 and soon became the main organ of the Ukrainian Social and Cultural society in Poland. With the help of "Nashe Slovo", editors aimed to explain the official position of Polish authorities in relation to Ukrainians, who were deported with force in 1947 from ethnic south-eastern lands to the outskirts of northern-west of Poland according to Vistula operation. Polish authorities also tried to use this newspaper order to improve the economic and social situation in Ukrainian families, who were dispersed all over Poland. Authorities encouraged Ukrainians to develop their native culture and education and also spread information about the socio-political and cultural life of Soviet Ukraine among Ukrainians in Poland.

Editors and authors of "Nashe Slovo" were forced to exalt the communist party leader, avoid certain topics (that were related to the persecution of their religious beliefs) and ignore certain historical events, because of the political situation. However, editors managed not to embody ideas of the official (Polish) authorities completely and turned the newspaper into an open "tribune" from which the Ukrainian community in Poland could talk about discrimination, the threat of assimilation and other problems. Since its inception newspaper tried to support Ukrainian national consciousness, helped to protect and defend their rights and to teach the Ukrainian language.

There were published many materials that documented the activity of the Ukrainian Social and Cultural Society, educational and cultural activities of Ukrainians in Poland, art exhibitions and literary evenings on the pages of this periodical. Since December, 1956 "Nashe Slovo" has launched a children supplement "Dytyachyy svit" (which later became known as "Svitanok") and from May, 1958 a popular scientific supplement "Nasha Kultura". Every year the editorial staff of "Nashe Slovo" supplied the Ukrainian anthology entitled "Ukrainian calendar" and helped to publish it.

"Nashe Slovo" published Ukrainian authors not only from Poland and the Soviet Union, but also from Czechoslovakia and Romania, that played a significant role in the preservation of Ukrainian culture and language. Despite some political and ideological constraints, magazine was popular among the Ukrainian-speaking audience, and its issues aroused significant interest among Ukrainian communities all over the world 
[Tyma, 2010, p. 30].

Since the magazine had such an independent editorial policy, unlike other minority periodicals, distribution of "Nashe Slovo" was forbidden on the territory of Soviet Ukraine, but still it was really popular among Western Ukrainian diaspora of all continents.

Later in the early 1980s, Polish government deprived "Nashe Slovo" of state funding because of its independent editorial policy. It caused a drop in circulation of the newspaper and, as a consequence, the loss of its popularity among the Ukrainian diaspora. Weekly newspaper "Nashe Slovo" gradually began to win back lost ground only after the fall of the communist government in Poland in the late 1989 and Ukraine's independence restoration.

Since 1990 "Nashe Slovo" is not an official organ of the Association of Ukrainians in Poland anymore and became the Ukrainian-speaking Polish newspaper.

Since that time it was published primarily to the Ukrainian community in Poland. With the help of "Nashe Slovo" readers could learn about the major events that took place in Poland, in Ukraine, and in the world, about the culture of two nations and their international relations, about historical events that had an impact on Poland and Ukraine. It also provided reviews of interesting books which were published in Poland, Ukraine, and others countries. In addition, editors of the newspaper paid attention to Ukrainian migrant workers and printed for them legal advices and practical materials on how to get accustomed to a new place and adapt in Polish society. According to the chief editor J. Prystasz, the main aim of "Nashe Slovo" was "to reflect the modern problems and to help the second and the third generation of Ukrainians who were born in Poland after Operation Vistula" [Surowska, 2012, p.7].

Along with coverage of contemporary issues, the editors focus on the constant appeal to history, as the national minorities in each state have their own points of view, which sometimes differ from the declarations of the national authorities. Therefore appeal to traditional history shapes the consciousness and identity of such communities. On History page in the "Nashe Slovo" there are published scientific research, autobiographical materials of prominent figures of Ukrainian origin, memories and memoirs. According to the notes of researcher T. Pron, "in historical publications editorial staff recognizes, primarily, an educational function. They publish articles of professional journalists, public figures and scientists from Poland and Ukraine, who represent not only historiographical narratives, but also documentary sources of Polish archives and eyewitness accounts"[Pron, 2010, p. 148].

Trying to keep pace with the times and to encourage the younger readers, editors of "Nashe Slovo" developed an electronic edition of the newspaper. On the website readers can find video and short articles that later appear in the full version. Editors even consider it to transform fully into electronic publishing and to launch the Internet subscription, so that readers will be able to see the full version of the newspaper after paying a certain fee.

Nowadays, despite many problems "newspaper «Nashe Slovo» successfully combines professional socio-political analysis of popular narrative, makes an important contribution to maintaining the identity of the Ukrainians in Poland. It still forms historical consciousness and protects Ukrainian community in Poland from unfair authors, who spread negative stereotypes about Ukrainians and interfere peaceful friendly coexistence in Polish society" [Pron, 2010, p. 148].

The weekly newspaper "Nashe Slovo" continues to consolidate two neighboring nations and contributes significantly to the development of two independent states. Review of the newspaper shows that the basis of its journalistic publications is the experience of the Ukrainian community in Poland, the consolidation of Ukrainian people, the restoration of historical justice. 


\section{References}

SOKOLYUK, Z. (1965) Ukrainska presa na chuzyni [in:] Ukrainskyj samostijnyk, 94, 1965.

KEDRYN, I. (1986) U mezah zacikawlennia.

TYMA, P. (2010) Media menshyn nad Wisloju [in:] Ukrainskyj zurnal, ch.7 2010.

SUROWSKA, O. (2012) "Nashe Slovo" na sluzbi w ukrajinciw [in:] Galychyna, 17 March 2012.

PRON, T. (2010) Ukrajinskyj tyznewyk "Nashe Slovo" (Warshawa) jak oryginalne dzerelo wywchennia peredumow i perebigu prymusowogo pereselenni aukrajinciw Polshchi w 1944-1947 rr. [in:] Istorychnyj arhiw, Wyp 52010. 